\title{
Projeto: Concurso de Fotografias para Pacientes de Hospital Neuropsiquiátrico
}

\author{
Oliveira, Graça Maria Ramos de; Hirschfeld, Arthur; Macedo, Danila Julieta \\ Magalhães; Vasconcelos, Ilse de Carvalho S.; Siqueira, Marcia Marques; Almeida, \\ Jouce Gabriela de \\ Instituto da Psiquiatria do Hospital das Clínicas da Faculdade de Medicina da Universidade de São \\ Paulo - IPq/HCFMUSP — gmropp@gmail.com
}

Introdução: a evolução tecnológica dos serviços de saúde foi fundamental e necessária para a qualidade na assistência, por outro lado parece ter sido acompanhada por uma maior escassez nas relações humanas. ao se falar em Humanização dentro do Hospital, busca-se não somente um atendimento mais humanizado, mas também valorizar a pessoa, o espaço que frequenta e seu cuidado. Este relato se refere à segunda edição de concurso interno de fotografias, realizado em 2013, voltado exclusivamente aos pacientes ambulatoriais e internados da instituição. o projeto teve início em 2012, mas à época envolveu apenas funcionários. Objetivo: Estimular os pacientes a realizarem ensaios fotográficos (preto e branco ou colorido), nas dependências da Instituição, exercitando um olhar diferente e novas perspectivas de seu local de tratamento, como forma de inclusão e ampliação de variáveis terapêuticas. Métodos: o concurso foi aberto para todos os pacientes (ambulatoriais e internados), mediante a comprovação por meio do número de matrícula e agendamento médico pelo menos nos últimos três meses. Os pacientes puderam utilizar máquina fotográfica própria ou fornecida pela Instituição (equipamento doado pela iniciativa privada para esse projeto). Os que optaram utilizar a máquina da Instituição participaram de aula para orientação de manuseio do equipamento e de dicas de fotografia, sendo acompanhados por um membro da comissão organizadora durante as incursões fotográficas. Cada paciente inscrito pôde apresentar até três fotos para concorrer à premiação. a comissão julgadora, composta por cinco jurados técnicos, escolheram as melhores fotos, julgando aspectos relativos à criatividade, estética, qualidade artística e pertinência com o tema proposto. Resultados: no dia em que a Instituição teria um evento aberto e voltado à população, todos os pacientes inscritos nesse concurso foram convidados a comparecer, momento em que os cinco primeiros colocados foram premiados e uma foto de cada um dos demais participantes foi exposta também, permanecendo no hall de entrada durante cerca de 30 dias. Tanto as cinco fotos vencedoras como uma de cada um dos outros dez participantes integraram o calendário do ano de 2014 da Instituição, que foi presenteado a todos os funcionários, além de distribuído a esses quinze pacientes. Conclusão: o lugar de tratamento na maioria das vezes está ligado a sentimentos ambíguos: agradecimento por se sentir acolhido e cuidado, mas também um lugar onde se presenciam ou se vivenciam sofrimentos diversos. ao se propor que os pacientes olhem para este espaço de forma lúdica ou artística, existe a possibilidade de transformação interna e se acomode este aspecto de vida de uma maneira mais amena e agradável, ampliando-se a visão que se tem da Instituição de tratamento e outorgando a cada um o poder de representá-la da forma mais humanamente subjetiva.

Oliveira, Graça Maria Ramos de; Hirschfeld, Arthur; Macedo, Danila Julieta Magalhães; Vasconcelos, Ilse de Carvalho S.; Siqueira, Marcia Marques; Almeida, Jouce Gabriela de. Projeto: Concurso de Fotografias para Pacientes de Hospital Neuropsiquiátrico. In: Anais do Congresso Internacional de Humanidades \& Humanização em Saúde [= Blucher Medical Proceedings, num.2, vol.1]. São Paulo: Editora Blucher, 2014. ISSN 2357-7282

DOI 10.5151/medpro-cihhs-10531 